Correction

\title{
Correction: Littink, K. W.; et al. Autosomal Recessive NRL Mutations in Patients with Enhanced S-Cone Syndrome. Genes 2018, 9, 68
}

Karin W. Littink ${ }^{1}$, Patricia T.Y. Stappers ${ }^{1}$, Frans C.C. Riemslag ${ }^{1,2}$, Herman E. Talsma ${ }^{1,2}$, Maria M. van Genderen ${ }^{2}$, Frans P.M. Cremers ${ }^{3,4}$, Rob W.J. Collin ${ }^{3,4}$ (i) and

L. Ingeborgh van den Born ${ }^{1, *}$

1 The Rotterdam Eye Hospital, 3011 BH Rotterdam, The Netherlands; k.littink@oogziekenhuis.nl (K.W.L.); p.stappers@oogziekenhuis.nl (P.T.Y.S.); FRiemslag@gmail.com (F.C.C.R.); HTalsma@bartimeus.nl (H.E.T.)

2 Bartiméus Center for Complex Visual Disorders, 3703 AJ Zeist, The Netherlands; mvgenderen@bartimeus.nl

3 Department of Human Genetics, Radboud University Medical Center, 6525 GA Nijmegen, The Netherlands; Frans.Cremers@radboudumc.nl (F.P.M.C.); Rob.Collin@radboudumc.nl (R.W.J.C.)

4 Donders Institute for Brain, Cognition and Behaviour, Radboud University Medical Center, 6525 GA Nijmegen, The Netherlands

* Correspondence: born@eyehospital.nl; Tel.: +31-10-4017777

Received: 2 March 2018; Accepted: 5 March 2018; Published: 7 March 2018

The authors wish to make the following correction to this paper [1]. Due to mislabeling, replace:
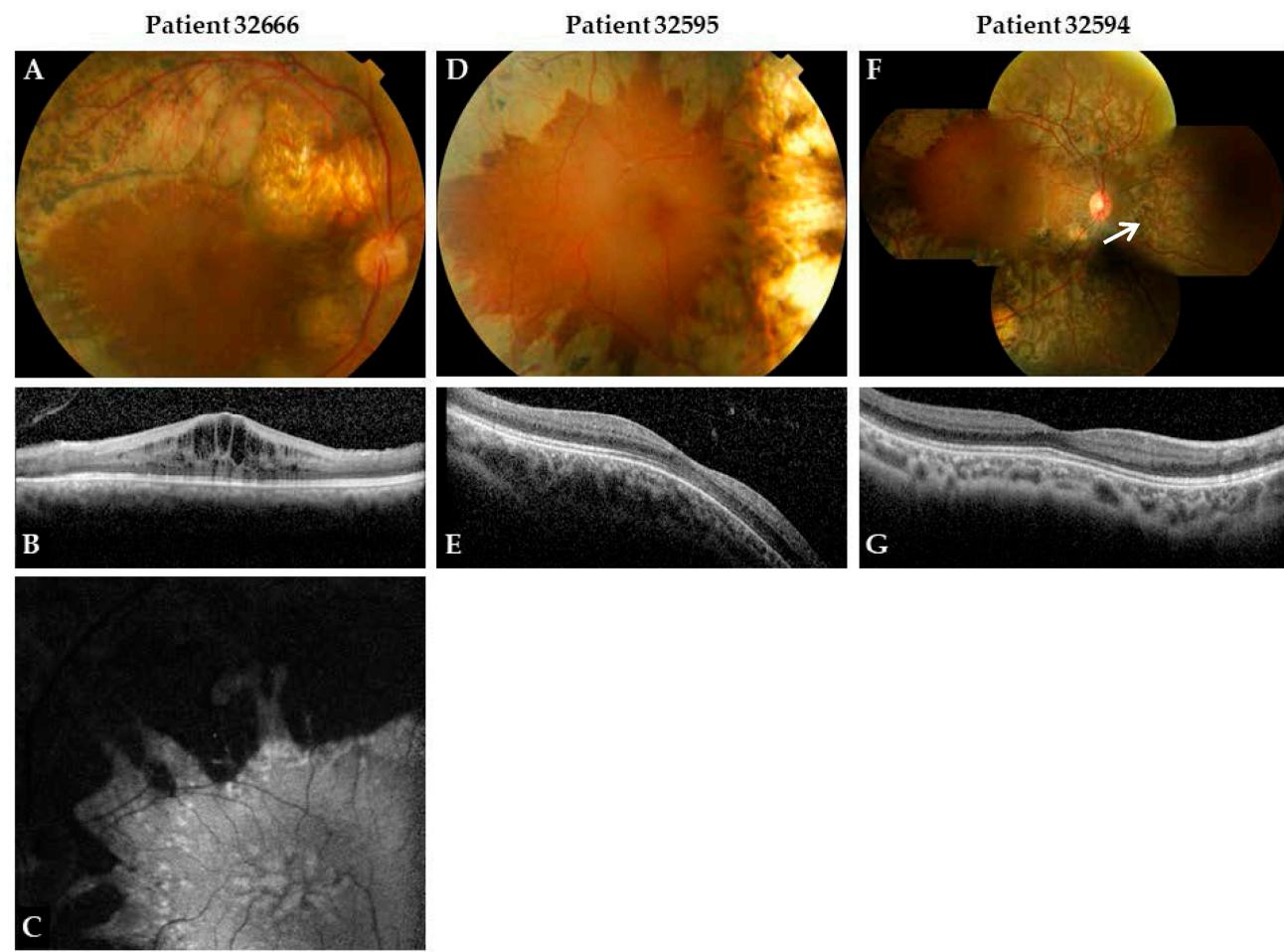

with 

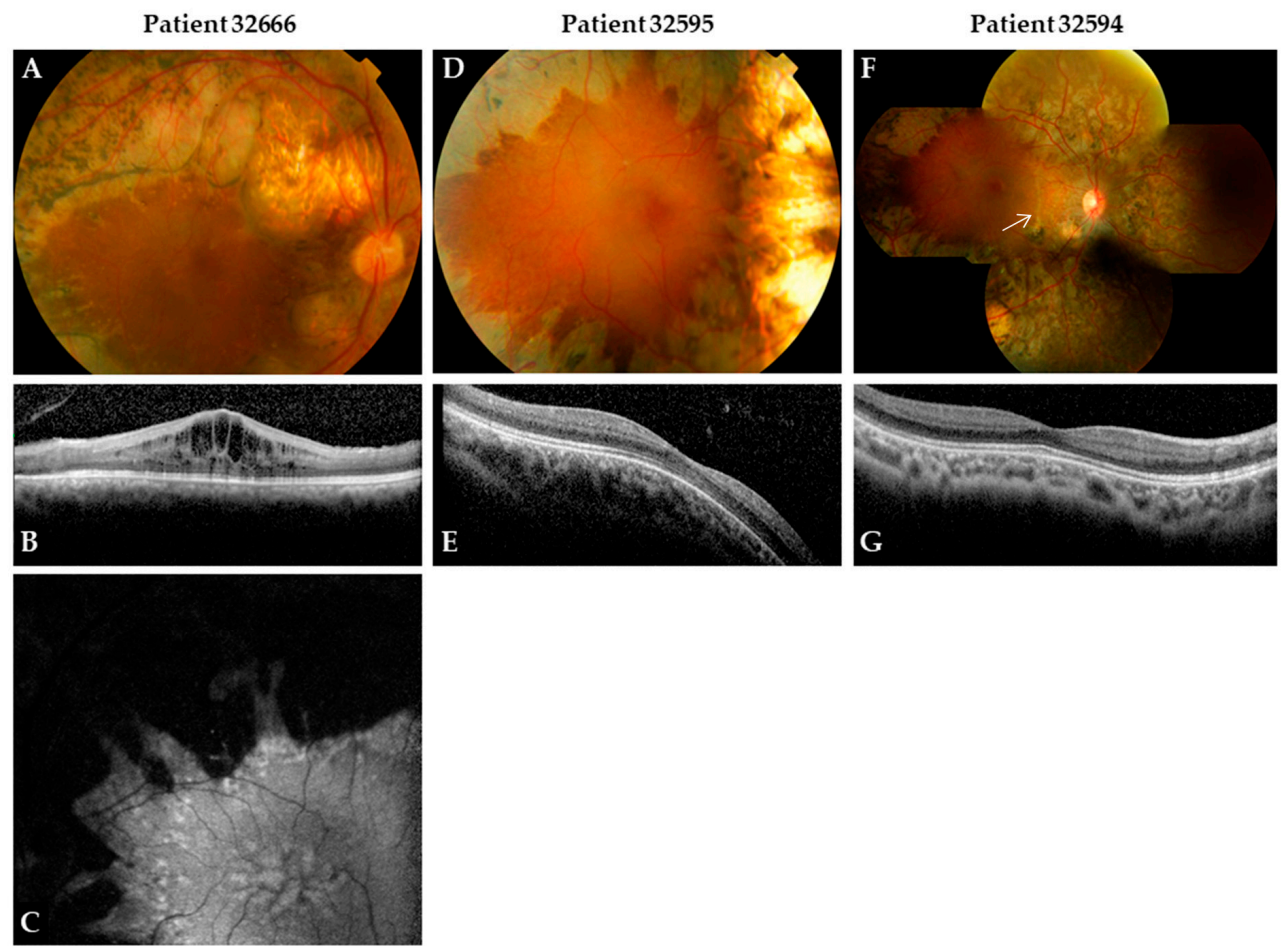

The authors would like to apologize for any inconvenience caused to the readers by these changes.

\section{Reference}

1. Littink, K.W.; Stappers, P.T.Y.; Riemslag, F.C.C.; Talsma, H.E.; van Genderen, M.M.; Cremers, F.P.M.; Collin, R.W.J.; van den Born, L.I. Autosomal Recessive NRL Mutations in Patients with Enhanced S-Cone Syndrome. Genes 2018, 9, 68. [CrossRef] [PubMed]

(c) 2018 by the authors. Licensee MDPI, Basel, Switzerland. This article is an open access article distributed under the terms and conditions of the Creative Commons Attribution (CC BY) license (http:/ / creativecommons.org/licenses/by/4.0/). 